\title{
ANALISIS PENGGUNAAN MEDIA BUKU TEKS DALAM PEMBELAJARAN BAHASA INDONESIA PADA MATERI MEMBUAT SINOPSIS NOVEL REMAJA INDONESIA KELAS VIII C DI SMP NEGERI 2 SAWAN
}

\author{
Oleh \\ Elisabeth Pinis ${ }^{1}$, Ida Bagus Sutresna², Ida Ayu Md. Darmayanti ${ }^{3}$ \\ Jurusan Pendidikan Bahasa dan Sastra Indonesia, Fakultas Bahasa dan Seni \\ Universitas Pendidikan Ganesha \\ Singaraja, Indonesia \\ e-mail: \{piniselisabeth@gmail.com, sutresna1956@gmail.com, \\ dayudarmayanti1984@yahoo.com\}@undiksha.ac.id
}

\begin{abstract}
ABSTRAK
Penelitian ini bertujuan mendeskripsikan (1) pembelajaran bahasa Indonesia melalui penggunaan media buku teks pada materi membuat sinopsis novel remaja Indonesia di kelas VIII C di SMP Negeri 2 Sawan dan (2) kendala-kendala yang memengaruhi ketidakefektifan penggunaan media buku teks dalam pembelajaran bahasa Indonesia pada materi membuat sinopsis novel remaja Indonesia di kelas VIII C di SMP Negeri 2 Sawan. Hasil penelitian ini diharapkan dapat memberikan manfaat bagi beberapa pihak, baik secara teoretis maupun praktis. Subjek penelitian ini adalah siswa dan guru kelas VIII C SMP Negeri 2 Sawan, sedangkan objek penelitian ini yakni pembelajaran dan kendala-kendala yang memengaruhi ketidakefektifan penggunaan media buku teks pada pembelajaran bahasa Indonesia dalam membuat sinopsis novel remaja Indonesia. Penelitian ini menggunakan metode pengumpulan data berupa observasi, wawancara, dan dokumentasi. Data dianalisis dengan menggunakann teknik analisis data deskriptif kualitatif. Hasil penelitian menunjukkan (1) pembelajaran bahasa Indonesia dalam materi membuat sinopsis remaja Indonesia lebih terfokus pada buku teks. (2) Kendala-kendala yang memengaruhi ketidakefektifan pembelajaran pada materi membuat sinopsis novel remaja Indonesia, yakni berasal dari faktor guru dan siswa. Kendala yang dirasakan oleh guru di antaranya guru kekurangan waktu dalam proses pembelajaran dan membuat siswa agar tidak mudah bosan untuk mendengarkan materi yang dijelaskan. Selanjutnya, kendala yang dirasakan oleh siswa di antaranya, tidak semua siswa memiliki buku teks, sulit memahami contoh sinopsis novel pada buku teks, kemampuan siswa dalam membuat sinopsis novel remaja Indonesia sangat rendah, menemukan novel remaja Indonesia cukup susah, serta membaca novel membutuhkan kosentrasi dan waktu yang cukup lama.
\end{abstract}

Kata-kata Kunci: Media Buku teks, Pembelajaran bahasa Indonesia membuat sinopsis novel

\section{ABSTRACT}

This study aims to describe (1) learning Indonesian through the use of text book media on the material to make a synopsis of Indonesian adolescent novels in class VIII C in SMP Negeri 2 Sawan and (2) constraints that affect the ineffectiveness of text book media 
use in learning Indonesian at material make synopsis of adolescent novel Indonesia in class VIII C in SMP Negeri 2 Sawan. The results of this study is expected to provide benefits for some parties, both theoretical and practical. The subject of this study are students and teachers of class VIII C SMP Negeri 2 Sawan, while the object of this study, namely learning and constraints that affect the ineffectiveness of the use of textbook media on learning Indonesian in making synopsis of adolescent novel Indonesia. This research uses data collection method in the form of observation, interview, and documentation. Data were analyzed by using qualitative descriptive data analysis technique. The results showed (1) Indonesian language learning in the material made the Indonesian teen synopsis more focused on text books. (2) Constraints affecting the ineffectiveness of learning in the material make synopsis of adolescent novel Indonesia, that is derived from factor of teacher and student. Constraints felt by teachers, including teachers lack of time in the learning process and make students not easily bored to listen to the material described. Furthermore, the obstacles felt by students, among them not all students have textbooks, difficult to understand examples of novel synopsis of text books, students' ability in making synopsis of teen novels Indonesia is very low, finding novel teenagers Indonesia is quite difficult, and reading novel requires concentration and a long time.

Keywords: Media Text books, Indonesian Lessons create a novel synopsis

\section{PENDAHULUAN}

Peran pendidikan sangat penting demi kemajuan suatu bangsa. Menurut Denemark (dalam Hamalik, 2006: 62), pendidikan adalah sesuatu yang sangat penting dalam masyarakat modern, baik segi politik maupun dari segi ekonomi. Itu sebabnya, pendidikan bukan saja hal yang penting bagi individu, melainkan juga sangat penting bagi kehidupan nasional (Hamalik, 2006: 62). Selain itu, untuk meningkatkan kualitas sumber daya manusia perlu adanya peningkatan kualitas pendidikan. Peningkatan kualitas pendidikan dapat dilihat melalui kebijakan-kebijakan pemerintah yang tentu dapat meningkatkan kualitas dan kuantitas pendidikan. Salah satu kebijakan yang terjadi pada bidang pendidikan, yakni adanya perubahan kurikulum. Menurut Sriasih (2008: 4), kebijakan di bidang kurikulum merupakan kebijakan yang mendasar, yang berimplementasi terhadap kebijakan-kebijakan yang lain.

Kurikulum pendidikan di Indonesia telah mengalami beberapa kali pergantian. Pergantian ini tiada lain dimaksudkan untuk senantiasa menyesuaikan alam pendidikan dengan perkembangan ilmu pengetahuan, teknologi, dan seni. Kurikulum sebagai pedoman mengajar mempunyai karakteristik fleksibel dalam kurun waktu tertentu harus direnovasi sehingga mempunyai nilai inovatif dan komunikatif (Sriasih, 2008: 5). Pada prinsipnya yang terjadi, perubahan kurikulum dalam kurun waktu tertentu adalah suatu kebutuhan.

Dalam usaha mencapai tujuan perkembangan nasional, pemerintah telah mengambil langkah-langkah kebijaksanaan, terutama dalam bidang pendidikan. Dalam bidang pendidikan, pemerintah telah merencanakan untuk meningkatkan mutu pendidikan melalui sistem pendidikan yang sesuai dengan 
tuntutan pembangunan di segala bidang yang memerlukan jenis-jenis keahlian dan keterampilan serta sekaligus dapat meningkatkan produktivitas, mutu, dan efisiensi kerja, seperti yang direncanakan dalam Garis-garis Besar Haluan Negara (GBHN) Republik Indonesia. Untuk mencapai mutu pendidikan yang memadai, pemerintah telah mengambil langkahlangkah ke arah pembaharuan, seperti yang telah disebutkan di atas, yakni perubahan kurikulum. Menurut Nurgiyantoro (2004: 92), tuntutan perubahan itu haruslah direspon oleh dunia pendidikan dan tanggapan secara konkret dilakukan oleh perubahan kurikulum untuk disesuaikan dengan kebutuhan masyarakat.

Salah satunya kurikulum 2013 (K-13). Seiring dengan pembaharuan kurikulum K-13 hingga saat ini, masih banyak sekolah, baik SD, SMP, maupun SMA/MA yang menggunakan Kurikulum Tingkat Satuan Pendidikan (KTSP) sebagai acuan dalam proses belajar mengajar. Menurut Sriasih (2008: 117), kurikulum yang ideal sebenarnya adalah kurikulum yang memperhatikan perbedaan-perbedaan yang dihadapi oleh masing-masing sekolah karena kenyataannya hampir setiap sekolah berada dalam kondisi yang berbeda-beda dalam banyak hal. Selain itu, kondisi dan kemampuan sekolah berbeda, kebutuhan, keinginan, motivasi, kesiapan, potensi, dan gaya belajar siswapun berbedabeda. Berkaitan dengan hal itu, pengembangan KTSP ini mengacu UU RI. No. 20 Tahun 2003 tentang Sistem Pendidikan Nasional dan Peraturan Pemerintahan RI. No. 19
Tahun 2005 tentang Standar Nasional Pendidikan (Sriasih, 2008: 118).

KTSP adalah kurikulum yang berbasis lingkungan, masyarakat, orang tua, dan sekolah. Faktor-faktor lingkungan yang dipertimbangkan di antaranya adalah kondisi geografi dan kondisi daerah sekolah penyelenggara pendidikan. Faktor-faktor masyarakat yang perlu dicermati adalah kondisi perekonomian, bisnis, kondisi sosial, kebutuhan, keinginan masyarakat, dan budaya. Faktor sekolah, misalnya, SDM-nya, fasilitas siswa dan lainnya. Dalam proses belajar mengajar, siswa sebagai subjek bina perlu dijadikan sasaran dalam pembinaan. Dalam artian, segala kegiatan terpusat pada siswa. Berdasarkan fungsi buku teks siswa, diharapkan pada proses belajar mengajar akan efektif apabila terjadi hubungan yang akrab antara siswa dan guru. Untuk membina hubungan antara guru dan siswa, diperlukan adanya media yang tepat dalam proses belajar mengajar. Salah satu media yang memperlancar hubungan guru dan siswa adalah buku teks. Buku teks bukan saja menjadi media yang memperlancar hubungan guru dengan siswa, melainkan juga hubungan siswa terhadap siswa yang lain, dan hubungan siswa terhadap sumber-sumber yang lain (Sriasih, 2008: 53).

Pemilihan buku teks sangat penting berkaitan dengan kualitas dan sesuai dengan kurikulum yang berlaku (KTSP). KTSP memberikan kebebasan penuh kepada sekolah untuk mengatur proses belajar mengajar sesuai dengan kemampuan siswa. Begitu juga, dengan pemilihan sumber belajar. Salah satunya, penggunaan media buku teks pada 
proses belajar mengajar. Menurut Sriasih (2008: 117), buku teks senantiasa menyesuaikan diri dengan kurikulum yang berlaku. Artinya, setiap orang yang akan menerbitkan sebuah buku harus mengikuti kurikulum yang berlaku. Selain itu, kehadiran buku teks harus mempunyai dua bentuk, yakni buku teks siswa dan buku teks guru. Kedua jenis buku teks ini dalam kehadirannya saling membutuhkan dan saling melengkapi, khususnya digunakan dalam pembelajaran.

Berkaitan dengan hal tersebut, buku teks yang digunakan harus sesuai dengan kurikulum yang berlaku sehingga pengaplikasian di sekolah tidak melenceng dari kurikulum yang berlaku. Menurut Muslich (2012: 63), Kurikulum Tingkat Satuan Pendidikan (KTSP) SD/MI, SMP/MTs, maupun SMA/SMK/MA bidang studi bahasa Indonesia yang merupakan perbaikan dari kurikulum 2004 harus dapat dioperasikan dalam pembelajaran. Standar Kompetensi (SK) dalam KTSP bidang studi bahasa Indonesia (yang memuat empat keterampilan berbahasa) harus dijabarkan lebih lanjut dalam format silabus yang memuat indikator yang operasional, materi pembelajaran yang sesuai, strategi pembelajaran yang kontekstual, jam pertemuan yang proporsional, dan alat evaluasi yang valid. Berdasarkan silabus itulah, guru dapat menyusun program tahunan (prota), program semester (promes), dan rencana pelaksanaan pembelajaran (RPP) yang siap dilaksanakan dalam pembelajaran bagi siswanya (Muslich, 2012: 63).

$$
\text { Untuk mencapai tujuan }
$$
pendidikan dan pengajaran bahasa dan sastra Indonesia, kurikulum, buku pelajaran, metode pengajaran, evaluasi pengajaran, guru perpustakaan, sekolah, dan lingkungan keluarga serta masyarakat memegang peranan penting. Kurikulum bahasa dan sastra harus luwes, memungkinkan guru dan peserta didik mengembangkan kreativitas dalam kegiatan belajar mengajar. Selain itu, isi dan cara penyajian buku pelajaran harus menarik dan menunjang pembinaan kemampuan dan keterampilan berbahasa dengan baik dan benar serta meningkatkan kemampuan apresiasi sastra.

Dalam pengajaran sastra, diperlukan proses belajar mengajar yang sekaligus melibatkan pengalaman, pengetahuan, dan penilaian peserta didik terhadap sastra secara langsung sehingga terjadi interaksi dinamis antara peserta didik, karya sastra, dan guru (Muslich, 2012: 335). Untuk mencapai tujuan keterampilan berbahasa, khususnya pada pembelajaran sastra, pemerintah mencantumkan materi ajar membuat sinopsis novel remaja Indonesia pada silabus Kurikulum Tingkat Satuan Pendidikan (KTSP) untuk Sekolah Menengah Pertama (SMP). Hal tersebut dapat dilihat dalam Standar Kompetensi (SK), yakni memahami teks drama dan novel remaja, sedangkan Kompetensi Dasar (KD), yakni membuat sinopsis novel remaja Indonesia.

Membuat sinopsis novel remaja Indonesia memang diperlukan empat aspek keterampilan dalam berbahasa, di antaranya berbicara, mendengarkan, membaca, dan menulis. Akan tetapi, yang paling 
penting adalah keterampilan membaca. Membaca adalah suatu proses berpikir, yang termasuk di dalamnya mengartikan, menafsirkan, dan menerapkan ide-ide dari lambang yang direpresentasikan dalam bentuk teks. Alasan memilih keterampilan membaca dibandingkan dengan keterampilan yang lain karena memiliki beberapa kelebihan yakni keterampilan membaca lebih fokus pada pemahaman, baik dari segi apresiasi maupun kreatif pembaca. Artinya, dalam hal ini, pembaca dituntut untuk menggunakan daya imajinasi untuk memahami isi keseluruhan sebuah teks, sehingga pembaca mampu memperoleh gambaran yang disajikan penulis. Hal ini juga dapat dikatakan membaca pemahaman apresiasi melibatkan seluruh dimensi kognitif sebelumnya karena apresiasi berkaitan dengan impak psikologi dan estetis terhadap teks (Sudiana, 2007: 34).

Membuat sinopsis berarti membaca novel secara keseluruhan, memahami, dan menuangkan kembali isi cerita melalui kegiatan menulis. Menurut Wirajaya dan Sudarmawati (2008: 96), sinopsis merupakan ringkasan suatu bacaan atau teks cerita yang mewakili dari kandungan isi bacaan atau teks cerita. Membuat novel remaja Indonesia berarti membuat sebuah ringkasan sebuah novel remaja, yang di dalam ringkasan tersebut berisi novel secara keseluruhan. Dalam proses membuat sinopsis novel, sangat diperlukan upaya pemahaman unsur-unsur novel tersebut.

Dengan adanya standar
kompetensi dan kompetensi dasar

tersebut, terbentuknya kecintaan siswa terhadap novel remaja Indonesia dan terlahir penulis novel yang andal. Namun, pada kenyataannya, pembelajaran membuat sinopsis novel remaja Indonesia sudah diajarkan, hanya wawasan siswa terhadap membuat sinopsis novel remaja Indonesia sangat berkurang. Dengan demikian, perlu adanya kerja sama antara guru, siswa, orang tua, dan fasilitas sekolah yang lain. Contohnya, penyediaan buku teks di perpustakaan sekolah yang memadai.

Berdasarkan pengalaman peneliti selama meneliti di kelas VIII C SMP Negeri 2 Sawan, kemampuan membuat sinopsis novel remaja Indonesia masih sangat rendah dibandingkan dengan kelas VIII A dan VIII B, yang sudah pasti diajarkan oleh guru bahasa Indonesia yang sama. Hal ini dapat dilihat dari kriteria ketuntasan minimal (KKM) siswa sebesar 78, sedangkan kemampuan siswa dalam membuat sinopsis novel remaja Indonesia di bawah nilai KKM. Hal tersebut dikarenakan oleh sulitnya siswa memahami contoh sinopsis yang terdapat dalam buku teks. Selain itu, siswa pada umumnya, tidak memiliki buku teks sebagai acuan pembelajaran. Tidak hanya itu, siswa juga kurang berminat dalam pembelajaran bahasa Indonesia, khususnya pada materi membuat sinopsis novel remaja Indonesia.

Berdasarkan hasil wawancara peneliti kepada guru bahasa Indonesia yang bernama I Made Sucita, yang menyatakan bahwa materi membuat sinopsis novel remaja Indonesia memang cukup susah untuk diaplikasikan ke siswa/siswi SMP. Hal 
ini terlihat ketika siswa ditugasi untuk membuat sinopsis novel remaja Indonesia, yakni siswa kurang mampu menyusun atau merangkai cerita dalam novel berdasarkan struktur yang jelas. Namun, siswa lebih banyak menulis ulang novel itu sendiri. Selain itu, peneliti juga mewawancarai salah satu siswi kelas VIII C SMP Negeri 2 Sawan yang bernama Amik. la mengatakan bahwa materi membuat sinopsis novel remaja merupakan materi yang cukup sulit. Tidak hanya itu, banyak kendala yang dialaminya, seperti tidak memiliki buku teks sebagai acuan, menemukan novel remaja cukup sulit, membutuhkan konsentrasi, dan menyita waktu yang cukup lama.

Dipilihnya SMP Negeri 2 Sawan sebagai tempat penelitian karena berbagai pertimbangan. Pertama, sebagian guru sudah banyak yang tersertifikasi. Kedua, hasil tulisan siswa yang dilihat dari hasil belajar siswa kurang baik. Ketiga, SMP Negeri 2 Sawan masih menggunakan KTSP. Keempat, SMP Negeri 2 Sawan dapat dikatakan sebagai sekolah di pedesaan dilihat berdasarkan letak geografisnya. Berdasarkan hal tersebut, tentunya peneliti ingin mengetahui proses belajar dan pembelajaran di SMPN 2 Sawan, khususnya pada materi membuat sinopsis novel remaja Indonesia.

Berdasarkan hal tersebut, peneliti hendak meneliti buku teks sebagai objek dalam penelitian ini. Hal ini dikarenakan oleh dalam pembelajaran, guru menggunakan buku teks sebagai media atau acuan dalam proses belajar mengajar. Berdasarkan wawancara peneliti kepada I Made Sucita, beliau mengatakan siswa diwajibkan memiliki buku teks sebagai pedoman pembelajaran. Hal ini bertujuan membantu dan mendorong siswa, memotivasi belajar, mempermudah konsep pemahaman, dan memungkinkan siswa untuk belajar mandiri. Namun, pada kenyataannya, masih ada siswa yang belum memiliki buku teks. Hal ini juga didukung oleh pengamatan peneliti saat observasi di kelas, banyak siswa yang tidak membawa buku teks. Ketika guru bertanya, banyak siswa beralasan tidak mempunyai buku teks dan ada juga yang mengatakan lupa membawa buku teks ke sekolah. Hal inilah yang akan menyebabkan proses belajar mengajar kurang efektif.

Penelitian penggunaan buku teks bukanlah penelitian baru di kalangan mahasiswa ataupun dosen. Sebelumnya penelitian penggunaan buku teks sebagai media sudah pernah diteliti oleh Supriyo (2015), Pendidikan Ekonomi FKIP Universitas Muhammadiyah Metro dengan judul Pengaruh Buku Teks dan Cetak terhadap Hasil Belajar di SMA N 1 Marga Tiga Kabupaten Lampung Timur pada Kelas XII IPS Tahun Pelajaran 2013/2014. Selain itu, sudah diteliti oleh saudari Mulyanti (2012), Jurusan Pendidikan Bahasa dan Sastra Indonesia, Universitas Pendidikan Ganesha dengan judul "Studi tentang Tingkat Keterbatasan Teks Bacaan dalam Buku Pelajaran Bahasa Indonesia Siswa Kelas VIII SMP Negeri 1 Sawan dengan Menerapkan Teknik Cloze". Penelitian sejenis juga pernah dilakukan oleh Anderiyanti (2015) dengan judul penelitian "Pengaruh Penggunaan 
Buku Paket terhadap Hasil Belajar Siswa pada Mata Pelajaran SAINS pada Materi Perubahan Sifat Benda di Kelas III SDN 19/1 Muara Tembesi".

Akan tetapi, ada beberapa
materi yang belum diteliti secara
mendetail oleh peneliti-peneliti
sehingga peneliti tertarik untuk
meneliti pembelajaran membuat
sinopsis novel remaja Indonesia di
kelas VIII C di SMP Negeri 2 Sawan
dengan judul Analisis Penggunaan
Media Buku Teks dalam
Pembelajaran Bahasa Indonesia
pada Materi Membuat Sinopsis
Novel Remaja Indonesia Kelas VIII
C di SMP Negeri 2 Sawan.
Berdasarkan hal di atas, peneliti
nantinya akan mendeskripsikan
pelaksanaan pembelajaran bahasa
Indonesia dengan menggunakan
media buku teks dalam pembelajaran
membuat sinopsis novel remaja
Indonesia. Peneliti juga ingin
mengetahui kendala-kendala yang
memengaruhi proses belajar yang
dihadapi oleh guru dan siswa dalam
pembelajaran bahasa Indonesia pada
materi membuat sinopsis novel remaja
Indonesia.

\section{METODE PENELITIAN}

Penelitian ini menggunakan rancangan penelitian deskriptif. Penelitian deskriptif adalah suatu penelitian yang dilakukan dengan tujuan utama mendeskripsikan suatu keadaan. Dalam penelitian ini, peneliti menggunakan metode deskriptif kualitatif.

Penelitian ini dilakukan di SMP Negeri 2 Sawan yang beralamatkan di Jalan Raya Singaraja-Air Sanih, Desa Bungkulan, Kecamatan Sawan, Singaraja-Bali. Alasan peneliti memilih SMP Negeri 2 Sawan sebagai lokasi penelitian karena beberapa alasan: 1) sebagian guru sudah tersertifikasi; 2) berdasarkan pengalaman selama PPL-Real dan wawancara, dilihat dari hasil tulisan siswa, tulisan siswa kurang baik, khususnya di bidang karya sastra; 3) SMP Negeri 2 Sawan terletak di daerah pedesaan berdasarkan letak geografisnya. Namun, berada pada posisi yang strategis yakni, di pinggir jalan raya umum; dan 4) perpustakaan sebagai sumber pengetahuan tidak menunjang pembelajaran di sekolah. Hal ini dikarenakan, pada tahun 2005 perpustakaan SMP Negeri 2 Sawan mengalami musibah kebakaran.

Penelitian ini diharapkan
mampu mendeskripsikan pembelajaran bahasa Indonesia dalam menggunakan media buku teks pada materi membuat sinopsis novel remaja Indonesia di kelas VIII C di SMP Negeri 2 Sawan. Yang menjadi sumber data pada penelitian ini adalah berasal dari subjek dan objek penelitian. Tentunya, subjek penelitian ini adalah siswa dan guru kelas VIII C SMP Negeri 2 Sawan Tahun ajaran 2017/2018, sedangkan objek dalam penelitian ini adalah (1) pembelajaran bahasa Indonesia dengan menggunakan media buku teks pada materi membuat sinopsis novel remaja Indonesia kelas VIII C SMP Negeri 2 Sawan dan (2) kendala-kendala yang memengaruhi ketidakefektifan penggunaan media buku teks dalam pembelajaran bahasa Indonesia pada materi membuat sinopsis novel remaja Indonesia kelas VIII C SMP Negeri 2 Sawan.

Metode pengumpulan data merupakan cara peneliti menentukan 
metode setepat-tepatnya untuk memperoleh data. Dalam penelitian ini, peneliti menggunakan metode observasi, wawancara, dan dokumentasi. Data-data yang telah dikumpulkan, selanjutnya akan dianalisis menggunakan instrumen penelitian. Instrumen yang digunakan oleh penelitian ini adalah pedoman wawancara dan lembar observasi. Selanjutnya, data yang diperolah tentunya harus dikumpulkan, diseleksi, dan ditafsirkan (Sugiyono, 2010: 305). Proses tersebut dalam penelitian deskriptif harus dilakukan oleh peneliti berdasarkan pengetahuan, pengalaman, dan wawasan peneliti tentang penelitian yang sedang dilakukan.

Setelah pengumpulan data dilakukan, langkah berikut adalah pengolahan data dilakukan dengan menganalisis data tersebut menggunakan metode deskriptif kualitatif. Metode deskriptif kualitatif digunakan untuk menganalisis data hasil observasi, khususnya, wawancara.

\section{HASIL DAN PEMBAHASAN Hasil Penelitian}

Berdasarkan hasil observasi, dalam proses belajar mengajar di kelas, pada umumnya, guru menggunakan media buku teks sebagai pedoman pembelajaran. Akan tetapi, guru juga menggunakan beberapa strategi untuk mendukung media buku teks yang akan digunakan.Strategi yang dimaksud, yakni ceramah, membacakan teks, diskusi, tanya jawab, dan memberikan tugas. Melalui strategi yang telah disebutkan di atas, diharapkan siswa mampu mencapai hasil yang maksimal.

Berdasarkan hasil observasi, dalam proses belajar mengajar di kelas, selain guru sebagai fasilitator, guru juga berperan sebagai pembimbing. Guru sebagai pembimbing harus mampu menghidupkan suasana di kelas. Dalam artian, guru tidak harus monoton dengan materi pembelajaran. Akan lebih baik, jika diselipkan lelucon atau motivasi yang menarik perhatian siswa. Dengan hal tersebut, proses interaksi guru, siswa, dan sumber belajar akan jauh lebih menarik sehingga menciptakan keadaan yang aktif dan kondusif. Berikut akan dipaparkan secara terperinci terkait pelaksanaan pembelajaran.

Kondisi ruangan tenang ketika guru mulai memasuki ruangan kelas VIIIC. Sebagai pemimpin di kelas, ketua kelas dengan semangat memberikan aba-aba untuk mengucapkan salam kepada guru. Setelah selesai, guru melakukan pemeriksaan terhadap kesiapan siswa di antaranya, mengecek kehadiran, menyiapkan fisik, dan mental siswa. Kemudian, guru memfokuskan perhatian dan kenyamanan suasana siswa di kelas. Lalu, guru memulai kegiatan pembelajaran.

Kegiatan pembelajaran diawali dengan guru menyuruh siswa membuka buku teks halaman 96, mengungkapkan Kompetensi Dasar (KD), indikator, dan tujuan pembelajaran, lalu menulisnya di papan tulis. Berikut kutipannya. 
"Anak-anak, silakan membuka buku teks halaman 96. Pada buku teks sudah tertera tujuan pembelajaran yang harus dicapai pada pembelajaran kita kali ini"

Berdasarkan kutipan di atas, dapat dipahami bahwa sebelum guru memulai menjelaskan materi, terlebih dahulu guru memberitahu siswa untuk membuka buku teks sebagai media sekaligus sumber pengetahuan. Guru juga harus mengungkapkan kompetensi dasar (KD), indikator, dan tujuan pembelajaran. Hal inibertujuan menginformasikan dan mengarahkan pemikiran siswa terkait arah atau tujuan pembelajaran yang harus dicapai oleh siswa itu sendiri. Sebagai guru yang profesional, tentunya hal semacam di atas sudah dirancang berdasarkan rencana pelaksanaan pembelajaran (RPP) yang dibuat oleh guru mata pelajaran.

\section{Setelah Kompotensi Dasar} (KD), Indikator, dan tujuan pembelajaran sudah terlaksana, langkah selanjutnya, yakni guru menghubungkan materi membuat sinopsis novel remaja Indonesia dengan kehidupan sehari-hari siswa. Berikut kutipannya.

Guru: "Apakah kalian pernah membaca novel? Apa yang kalian ketahui tentang novel?"

(Beberapa siswa mengacungkan tangan, guru memilih siswa yang duduk paling pojok untuk menjawab pertanyaan).

Siswa 1: "Pernah. Novel adalah karya sastra yang berbentuk cerita, yang menceritakan kehidupan manusia."
Guru : "Baik, terima kasih. Apakah masih ada yang memberikan pendapat?"

Berdasarkan kutipan di atas, dapat dipahami bahwa sebelum guru menjelaskan materi, terlebih dahulu, guru mengadakan tes awal dalam bentuk lisan dengan memberikan beberapa pertanyaan yang terkait dengan materi yang akan diajarkan atau dipelajari. Pertanyaanpertanyaan tersebut mungkin akan lebih menjadi komunikatif antara siswa dan guru. Hal ini bertujuan mengetahui pengetahuan awal siswa terkait materi yang akan dipelajari. Dengan pertanyan-pertanyaan seperti itu, guru bisa memprediksi pengetahuan siswa terkait materi membuat sinopsis novel remaja Indonesia. Jika pemahaman awal siswa baik, guru dengan mudah membimbing dan mengarahkan pemahaman siswa, sedangkan, jika tidak, guru harus menjelaskan secara terperinci terkait materi yang ajarkan, sehingga pengetahuan siswa lebih terarah.

Selanjutnya, saat menjelaskan materi tentang membuat sinopsis novel remaja Indonesia, guru menggunakan metode ceramah. Hal ini ditunjukkan pada kutipan berikut.

Guru: "Baik anak-anak, coba perhatikan buku teks halaman 96. Sebelum kita mempelajari membuat sinopsis novel remaja Indonesia, terlebih dahulu, kita harus memahami pengertian novel dan unsur-unsur novel secara garis besar. Novel merupakan salah satu bentuk karya sastra fiksi yang perwujudannya sangat ditentukan oleh adanya unsur- 
unsur cerita yang satu dengan yang lainnya, yang diolah sedemikian rupa oleh penulis, berdasarkan pengalaman, baik dari penulis sendiri atau masyarakat sekitar sehingga menjadi sebuah karya sastra yang mengesankan. Adapun unsur-unsur novel, yakni unsur intrinsik dan ekstrinsik, sedangkan sinopsis novel merupakan ringkasan suatu bacaan atau teks cerita yang mewakili kandungan isi bacaan atau teks cerita."

Setelah itu, guru menjelaskan materi terkait materi sinopsis novel Indonesia. Terlebih dahulu, guru memberikan contoh sinopsis novel yang ada pada buku paket halaman 96 yang berjudul " Ronggeng Dukuh Paruk" Karya Ahmad Tohari. Hal ini dibuktikan pada kutipan berikut.

Guru: "Baik, anak-anak, untuk lebih memahami, perhatikan contoh teks sinopsis novel remaja Indonesia pada buku teks halaman 96 yang berjudul "Ronggeng Dukuh Paruk" karya Ahmad Tohari".

Berdasarkan kutipan di atas, guru mengharapkan siswa untuk fokus terhadap materi pelajaran, khususnya membuat sinopsis novel remaja Indonesia dan memperhatikan contoh teks sinopsis yang tercantum di buku teks halaman 96.Selanjutnya, guru menunjuk salah satu siswa untuk membacakan contoh sinopsis di depan kelas, sedangkan siswa yang lain diminta untuk memperhatikan dan menyimak bacaan yang sedang dibaca oleh teman di depan kelas. Setelah selesai, guru menyuruh siswa untuk membentuk kelompok, masingmasing anggota kelompok terdiri atas
4-5 orang. Guru meminta siswa untuk membaca kembali dan mendiskusikan secara berkelompok. Lalu, menemukan dan membuat kerangka sinopsis yang telah mereka baca. Yang terakhir adalah mempertanggungjawabkan hasil diskusi kelompok dengan membaca di depan kelas secara nyaring dari setiap kelompok, lalu dikumpulkan kepada guru.

Berdasarkan hal tersebut, pada pembelajaran ini, guru menggunakan metode diskusi. Hal ini bertujuan menciptakan interaksi atau bertukar pikiran melalui diskusi antara siswa dan siswa lainnya guna menemukan kerangka-kerangka sinopsis novel remaja Indonesia yang sudah dibacakan. Selain itu, melalui metode ini, guru juga menanamkan rasa tanggung jawab terhadap diri siswa, melalui kemampuan siswa dalam mengerjakan tugas secara berkelompok.

Pada kegiatan penutup, pertamatama, guru mengevaluasi melalui kegiatan tanya jawab dengan memberikan beberapa pertanyaan terkait materi yang sudah diajarkan. Untuk memotivasi belajar siswa, guru memberikan nilai tambahan kepada siswa yang menjawab pertanyaan guru selama proses tanya jawab. Setelah itu, guru mengakhiri pertemuan dengan mengucapkan salam.

\section{Pembahasan Penelitian}

Hasil penelitian meliputi pembelajaran bahasa Indonesia dalam menggunakan media buku teks pada materi membuat sinopsis novel remaja Indonesia di kelas VIII C di 
SMP Negeri 2 Sawan, (2) kendalakendala yang memengaruhi ketidakefektifan penggunaan media buku teks dalam pembelajaran bahasa Indonesia pada materi membuat sinopsis novel remaja Indonesia di kelas VIII C di SMP Negeri 2 Sawan.

Guru memulai pelajaran dengan meminta siswa membuka buku teks halaman 96. Kemudian, guru menulis di papan tulis dan mengungkapkan kembali KD, SK, Indikator, dan tujuan pembelajaran. Hal ini dimaksudkan untuk mengarahkan pemikiran siswa terkait materi yang akan dipelajari. Hal ini sejalan dengan pendapat Muslich (2012: 63), Standar Kompetensi (SK) dalam KTSP bidang studi bahasa Indonesia (yang memuat empat keterampilan berbahasa) harus dijabarkan lebih lanjut dalam format silabus yang memuat indikator yang operasional, materi pembelajaran yang sesuai, strategi pembelajaran yang kontekstual, jam pertemuan yang proporsional, dan alat evaluasi yang valid. Berdasarkan silabus itulah, guru dapat menyusun program tahunan (prota), program semester (promes), dan rencana pelaksanaanpembelajaran (RPP) yang siap dilaksanakan dalam pembelajaran bagi siswanya.

Dalam proses belajar mengajar di kelas, guru menggunakan media buku teks sebagai pedoman pembelajaran pada materi membuat sinopsis novel remaja Indonesia kelas VIII C SMPN 2 Sawan. Hal ini sejalan dengan pendapat Sriasih (2008: 22), buku teks merupakan buku pelajaran dalam bidang studi tertentu, yang merupakan buku standar, yang disusun oleh para pakar dalam bidang itu dengan maksud-maksud dan tujuan instruksional, yang diperlengkapi dengan sarana-sarana pengajaran yang serasi dan mudah dipahami oleh para pemakainya di sekolah-sekolah dan perguruan tinggi sehingga dapat menunjang suatu program pengajaran.

Selain menggunakan buku teks, dalam memberikan materi membuat sinopsis, guru juga menggunakan metode ceramah, diskusi, dan tanya jawab untuk menjelaskan materi secara terperinci. Hal tersebut sejalan dengan pendapat Roestiyah (2008: 36) yang mengatakan bahwa metode ceramah adalah suatu cara mengajar yang digunakan untuk menyampaikan informasi keterangan atau uraian tentang suatu pokok persoalaan serta masalah lisan. Pada tahap ini, guru juga berperan untuk menanyakan keterlibatan siswa dengan cerpen atau novel tersebut. Kemudian, guru meminta komentar siswa terkait kemampuan teknik pengarang dalam mengelola unsur-unsur cerpen atau novel, relevansi cerpen atau novel tersebut dengan kebutuhan siswa pribadi, kehidupan pribadi siswa, ataupun kehidupan masyarakat secara luas (Emzir, 2015: 255).

Selanjutnya, terkait kendalakedala yang memengaruhi ketidakefektifan penggunaan media buku teks dalam pembelajaran bahasa Indonesia pada materi membuat sinopsis novel remaja Indonesia kelas VIII C di SMP Negeri 2 sawan yakni guru dan siswa. 
Berdasarkan observasi yang
dilakukan saat pembelajaran berlangsung, siswa memiliki motivasi yang berbeda-beda dalam menerima pelajaran bahasa Indonesia, khususnya pada materi membuat sinopsis novel remaja Indonesia. Beberapa siswa memiliki motivasi dalam menerima pelajaran yang dibuktikan dengan antusias dalam belajar, memperhatikan guru saat mengajar, aktif dalam menjawab pertanyaan guru, ataupun bertanya ketika ada hal yang belum dimengerti. Akan tetapi, tidak sedikit siswa yang kurang memiliki motivasi selama kegiatan belajar mengajar. Hal ini ditunjukkan oleh sikap siswa yang tidak memperhatikan guru saat proses belajar mengajar berlangsung, mengobrol dengan teman sebangkunya, menggambar pada buku tulis, dan bahkan mengerjakan tugas yang tidak berkaitan dengan mata pelajaran bahasa Indonesia. Hal seperti itulah yang menyebabkan pembelajaran tidak kondusif. Namun, seperti yang telah dibahas pada hasil penelitian bahwa guru dan siswa juga mengalami kendala dalam melaksanakan pembelajaran bahasa Indonesia pada materi membuat sinopsis novel remaja Indonesia.

Terkait kendala tersebut, berdasarkan hasil wawancara peneliti dengan guru bahasa Indonesia yang mengajar di kelas VIII C, yaitu I Made Sucita, menjelaskan ketika mengajar dengan menggunakan media buku teks adalah siswa kurang memahami contoh pada buku teks. Hal ini juga dikarenakan oleh banyak siswa yang tidak mempunyai dan tidak membawa buku teks saat pembelajaran berlangsung. Dalam hal ini, guru cenderung memilih buku teks dengan mempertimbangkan buku teks mudah didapatkan, menarik, dan dapat dipahami oleh guru itu sendiri. Namun, guru jarang memilih buku yang mudah didapatkan, menarik, dan dapat dipahami oleh siswa. Hal tersebut didukung oleh pendapat Sriasih (2008: 34 ), seorang guru harus mampu memilih buku teks yang berkualitas dan bermutu, semakin baik kualitas buku teks, semakin sempurna pengajaran mata pelajaran yang ditunjangnya.

pada bagian penutup, yakni melaksanakan evaluasi. Evaluasi merupakan salah satu cara untuk mengetahui pemahaman siswa dan untuk mengetahui tercapainya tujuan pembelajaran. Penilaian yang dilakukan diharapkan tidak terlepas dari ranah kognitif, afektif, dan psikomotor. Setiap mengakhiri pelajaran guru diharapkan melakukan evaluasi untuk mengetahui siswa dapat memahami materi yang telah disampaikan atau tidak. Namun, pada proses pembelajaran berlangsung, guru kekurangan waktu dalam menyelesaikan pembelajarannya. Hal ini terlihat, guru tidak mengevaluasi pembelajaran secara keseluruhan, bahkan tidak memberikan tugas rumah atau tugas tambahan kepada siswa. Dengan melakukan evaluasi pada akhir proses pembelajaran, dapat meningkatkan keantusiasan/perhatian siswa dalam mengikuti kegiatan belajar.

Kemudian, kendala yang dihadapi oleh siswa dalam mengikuti proses belajar mengajar adalah siswa tidak memiliki buku teks sebagai pedoman pembelajaran. Hal ini juga 
berdampak pada keaktifan siswa yang monoton pada buku teks dalam mengikuti pelajaran. Ketika siswa memiliki buku, mereka bisa menjawab pertanyaan yang diberikan oleh guru, sedangkan siswa yang tidak memiliki buku teks diibaratkan sebagai pelengkap di ruangan kelas. Hal ini diakibatkan oleh kurangnya kesadaran siswa untuk memiliki buku teks siswa sebagai pendamping pembelajaran.

\section{Berdasarkan pengamatan}

penulis, selain permasalahan di ruangan kelas, permasalahan juga berkaitan dengan fasilitas yang dimiliki oleh sekolah untuk menunjang proses belajar mengajar di sekolah. Salah satu fasilitas yang sangat mendukung proses belajar mengajar adalah ketersedian buku teks di perpustakaan SMP Negeri 2 Sawan. Dengan fungsi teks sebagai sumber, akan memungkinkan siswa dapat belajar sendiri di rumahnya tanpa bimbingan guru, juga dapat dimanfaatkan di perpustakaan (Sriasih, 2008: 54).

\section{Implikasi Penelitian}

Berdasarkan temuan peneliti, hasil dan pembahasan penelitian, serta simpulan, penulis mengajukan beberapa implikasi. Penggunaan media pembelajaran berupa buku teks menuntut kesiapan siswa agar melaksanakan pembelajaran secara mandiri dan memiliki buku teks sebagai media pembelajaran sekaligus sumber pengetahuan. Dalam hal ini, guru hendaknya memilih media yang tepat atau mendukung pemahaman siswa dan dikondisikan dengan lingkungan siswa terkait bacaan yang akan digunakan.
Salah satunya ketersediaan buku teks pelajaran di perpustakaan sekolah.

Hal ini juga berdampak pada hasil belajar siswa yang memiliki buku teks dan tidak memiliki sangat berbeda. Hal ini dapat dilihat berdasarkan keaktifan siswa di kelas. Siswa yang memiliki buku teks cenderung aktif dibandingkan siswa yang tidak memiliki buku teks. Namun, siswa lebih berpatokan berdasarkan jawaban pada buku teks. Dengan demikian, diharapkan kesadaran siswa untuk lebih aktif dan mengutamakan pembelajaran. Untuk terwujudnya hal itu, orang tua juga ikut bertanggung jawab terhadap keberhasilan dan kemampuan anak, baik itu melalui bimbingan, arahan, ataupun menyediakan fasilitas anak yang dibutuhkan di sekolah.

Selain itu, pemerintah dan sekolah sebaiknya meningkatkan kinerja guru, melalui pelatihan yang dikeluarkan oleh kebijakan pemerintah dan sekolah, yang dapat mefasilitasi kebutuhan guru dalam meningkatkan keterampilan maupun kemampuan mengajar khususnya pada bidang sastra. Salah satunya melalui kegiatan ekstrakulikuler yang di keluarkan oleh pihak sekolah ataupun diadakan perlombaan yang berkaitan dengan karya sastra sehingga guru maupun siswa lebih mendalami rasa cinta terhadap apresiasi karya sastra.

\section{SIMPULAN DAN SARAN}

Berdasarkan hasil penelitian dan pembahasan di atas dapat disimpulkan sebagai berikut. Pertama, penggunaan media buku teks dalam pembelajaran bahasa Indonesia pada materi membuat sinopsis novel remaja 
Indonesia kelas VIII C SMP Negeri 2 Sawan, yaitu guru menggunakan media buku teks sebagai sumber atau pedoman pembelajaran. Sebelum melaksanakan pembelajaran, guru menyusun RPP berdasarkan silabus dan kurikulum yang berlaku, yakni KTSP dan selanjutnya diaplikasikan ke pembelajaran dengan bantuan media buku teks. Pada umumnya, saat pelaksanaan pembelajaran, guru menggunakan buku teks, mulai dari tujuan pembelajaran, materi pembelajaran, dan contoh teks khususnya pada materi membuat sinopsis novel remaja Indonesia. Berdasarkan hal tersebut, dapat dikatakan bahwa guru yang mengajar di kelas VIII C SMP Negeri 2 Sawan pada materi membuat sinopsis novel remaja Indonesia kurang memadai dalam menggunakan media buku teks. Kedua, kendala-kendala yang memengaruhi ketidakefektifan penggunaan media buku teks dalam pembelajaran bahasa Indonesia pada materi membuat sinopsis novel remaja Indonesia kelasa VIII C di SMP Negeri 2 Sawan, yakni berasal dari guru dan siswa. Kendala-kendala yang dialami oleh guru pada saat pembelajaran yakni guru kekurangan waktu dalam menyelesaikan pembelajaran dan cara membuat siswa agar tidak mudah bosan untuk mendengarkan materi, sedangkan, kendala-kendala yang memengaruhi siswa saat pembelajaran, yakni tidak semua siswa memiliki buku teks, siswa sulit memahami contoh sinopsis novel pada buku teks, kemampuan siswa dalam membuat sinopsis novel remaja Indonesia sangat rendah, menemukan novel remaja Indonesia cukup susah, membaca novel membutuhkan kosentrasi, dan waktu yang cukup lama. Selain itu, kurangnya ketersedian buku teks di perpustakaan SMP Negeri 2 Sawan sebagai sumber pengetahuan. Oleh karena itu, pembelajaran membuat sinopsis novel remaja Indonesia di kelas VIII C SMP Negeri 2 Sawan kurang memadai.

Berdasarkan simpulan di atas, dapat diajukan beberapa saran terkait dengan hasil penelitian yang dilakukan oleh peneliti sebagai berikut. (1) Saran bagi guru. Pertama, guru bahasa Indonesia hendaknya mampu mengembangkan proses belajar mengajar menjadi lebih menarik dan bervariasi, serta meningkatkan kreativitas apresiasi sastra dalam pencapaian hasil belajar yang maksimal. Kedua, guru bahasa Indonesia harus mampu memberikan solusi terhadap kendala-kendala yang dihadapi oleh siswa saat pembelajaran membuat sinopsis novel remaja Indonesia. (2) Saran bagi siswa. Siswa hendaknya lebih aktif dalam proses belajar sehingga mampu meningkatkan kemampuan pemahaman siswa terkait membuat sinopsis novel remaja Indonesia. (3) Saran bagi pihak sekolah. Bagi pihak sekolah, penelitian ini dapat dijadikan bahan pertimbangan untuk mengambil kebijakan atau tindak lanjut terhadap kelangsungan proses pembelajaran yang dilaksanakan oleh guru, khususnya penyediaan fasilitas buku teks. (4) Bagi peneliti lain, diharapkan dapat melakukan penelitian sejenis dengan cakupan yang lebih luas sehingga jangkauan wawasan penelitian ini semakin luas.

\section{DAFTAR RUJUKAN}


Emzir dan Saifur Rohman. 2015. Teori dan Pengajaran Sastra. Jakarta: PT. Raja Grafindo Persada.

Hamalik, Oemar. 2006. Pendidikan Guru Berdasarkan Pendekatan Kompetensi. Jakarta: PT. Bumi Aksara.

Muslich, Masnur. 2012. Bahasa Indonesia pada Era Globalisasi. Jakarta: Bumi Aksara.

Nurgiyantoro, Burhan. 2013. Teori Pengkajian Fiksi. Yogyakarta: Universitas Gadjah Mada.

Roestiyah, N.K. 2008. Strategi Belajar Mengajar. Jakarta: PT RINEKA CIPTA

Sriasih, Sang Ayu. 2008. Telaah Buku Teks. Buku Ajar/modul (belum diterbitkan). Singaraja: Universitas Pendidikan Ganesha.

Sugiyono. 2010. Metode Penelitian Pendidikan. Bandung: Alvabeta.

Wirajaya. A \& Sudarmawati. 2008. Berbahasa dan Bersastra Indonesia untuk SMP/MTS Kelas VIII. Jakarta: Pusat Perbukuan Departemen Pendidikan Nasional Tahun 2008.

\section{JURNAL}

Nurgiyantoro, Burhan. 2004. "Penilaiaan Pembelajaran Sastra Berbasis Kompetensi" FBS Universitas Negeri Yogyakarta. Diksi Volume 11, No.1 